\title{
Study on the Productive and Reproductive Performances of BLRI-1 and BLRI-2 Ducks in Bangladesh
}

\author{
M. S. Islam*, H. Khatun, M. N. Islam, S. Faruque and M. S. K. Sarker \\ Poultry Production Research Division, Bangladesh Livestock Research Institute. Savar, \\ Dhaka, Bangladesh \\ *Corresponding author and Email: siraj_blri@yahoo.com
}

Received: 24 September $2013 \quad$ Accepted: 14 June 2014

\begin{abstract}
A total of 887 ducklings of BLRI-1 duck genotype and 352 ducklings of BLRI-2 duck genotype were studied to measure productive and reproductive performances under intensive management. Data were recorded on body weight, egg production, egg weight, fertility, embryonic mortality, hatchability, feed intake, age at sexual maturity, body weight at maturity and egg weight at maturity. The fertility rate in BLRI-1duck was significantly $(p<0.01)$ higher than that of BLRI-2 duck, while hatchability of BLRI-2 duck on fertile eggs were significantly $(p<0.05)$ better compared to BLRI-1 duck. The embryonic mortality was significantly $(p<0.01)$ higher in BLRI-2 duck than BLRI-1 duck. Duckling weight was influenced by egg weight $(p<0.05)$ but difference in duckling: egg ratio was not significant $(p>0.05)$. Hatching weight, $4^{\text {th }}$ week and $12^{\text {th }}$ week of age were significant $(p<0.05)$ influent while the body weight of ducks at $8^{\text {th }}$ week did not differ significantly $(p>0.05)$ for BLRI-1 and BLRI-2 ducks, respectively. The least squares mean for age at sexual maturity were 158 days and 151.75 days, respectively for BLRI-1 and BLRI-2 ducks $(p<0.05)$. BLRI-1 duck started to lay eggs almost one week late compared to BLRI-2 duck. Duck weight at sexual maturity, egg weight at first lay and egg production did not have significant $(p>0.05)$ difference between genotypes. It may be concluded that BLRI-2 duck genotype is superior in terms of hatchability and age at sexual maturity to BLRI-1 duck genotype.
\end{abstract}

Keywords: Native ducks, body weight, age at sexual maturity, egg production

\section{Introduction}

Native ducks have been well adapted to local climate and are considered to be dual purpose type. Duck population has been estimated at 42.68 million occupying second position in poultry in Bangladesh (Pervin et al., 2013). Native ducks like Pati (Deshi), Nageswari, Sylhet Mete, Cinahanh constitute about $97-98 \%$ of the total duck population, whereas the rest constitute exotic breed like Indian Runner, Khaki Campbell, Jending and Pekin (Sing and Moore,
1978; Huque and Hussain, 1991). Native ducks play a vital role for income generation, nutritional fulfilment and employment generation in the low-lying areas of Bangladesh (Islam et al., 2003). Ducks of the country have been under utilized and less emphasis was given to improve native ducks through pedigree selection and breeding (Ukil and Islam, 1991 and Salam and Uddin, 1987).

Bangladesh Livestock Research Institute (BLRI) initiated native duck breeding program to 
conserve five types of native ducks since 1999 . Since then, several experiments have been conducted to improve the production performance of native ducks under intensive management. Thus, phenotypic, productive and reproductive characteristics of two native ducks were improved by selective breeding (Khatun $e t$ al., 2010). After verification, comparative better performers of two native ducks were named as improved ducks of BLRI-1 and BLRI-2. However, records on egg production, egg weight, body weight, fertility, hatchability and age at sexual maturity of BLRI-1 and BLRI-2 ducks are scanty. Therefore, this study was conducted to evaluate the productive and reproductive performances of BLRI-1 and BLRI2 ducks under intensive management system.

\section{Materials and Methods}

This study was conducted at the duck breeding research farm under Poultry Production Research Division (PPRD), BLRI, Savar, Dhaka, Bangladesh. A sex ratio of (5:1) was maintained to obtain hatching eggs from experimental duck breeding flock. Eggs were incubated in Petersime incubator (capacity 8400 eggs in each hatch) under the hatchery of PPRD. A total of 887 ducklings of BLRI-1 and 352 ducklings of BLRI-2 were hatched in two batches, two weeks apart from October to November 2012. Ducklings were brooded on both slat and cage in duck brooding shed. Ducks were reared in a natural-ventilated duck house.

Sixteen hours photoperiod was maintained during laying period. Diet contains $20.50 \% \mathrm{CP}$ \& $3000 \mathrm{kcal} \mathrm{ME} / \mathrm{Kg} \mathrm{DM} ; 18.40 \% \mathrm{CP} \& 2775$ $\mathrm{kcal} \mathrm{ME} / \mathrm{Kg} \mathrm{DM}$ and $17.50 \% \mathrm{CP} \& 2750 \mathrm{kcal}$ $\mathrm{ME} / \mathrm{kg} \mathrm{DM}$ were provided twice daily in the morning and afternoon during brooding (0-6 weeks), growing (7-18 weeks) and laying period, respectively. On an average $155 \mathrm{~g}$ feed was provided to each duck during laying period. The ducklings were identified by leg-band to maintain pedigree record. Wing bands were applied in wing after removing leg-band from leg at 21 days of age.
Ducks were vaccinated against duck plague and duck cholera. Strict bio-security measures and hygienic control were taken for obtaining better healthy ducks. Each laying duck was kept in an individual coop for maintaining individual egg production record. During incubation, fertility, embryonic mortality and hatchability record were kept in a hatch out register book. Individual body weight was recorded at hatch, $4^{\text {th }}$ week, $8^{\text {th }}$ week and $12^{\text {th }}$ weeks of age by an electronic balance. Body weight at sexual maturity, egg production, egg weight, mortality, feed intake were also recorded in research data recording register during the study period. Data were analyzed using univariate GLM procedure of SPSS 10.0 for Windows (SPSS Inc. 1998) computer programme. The differences in means were tested using Least Significant Difference (LSD) method.

\section{Results and Discussion}

Fertility, embryonic mortality and hatchability rate of BLRI-1 and BLRI-2 ducks are shown in Table 1. Fertility rate of BLRI-1 duck (65.98\%) was significantly $(p<0.05)$ higher than that of BLRI-2 duck (59.59\%). Hamid et al. (1988) reported that the fertility of local duck was $78.75 \%$, which was higher than that is the present study. This result may be attributed to seasons, male female ratio, egg collection and disinfection, egg storage, age of ducks etc. The embryonic mortality was 24.94 and $35.81 \%$, respectively, for BLRI-1 and BLRI-2 duck and the difference was significant $(p<0.01)$. Hocking (2009) reported that egg quality, sanitary condition, storage condition, incubator quality and gas exchanges $\left(\mathrm{O}_{2}\right.$ and $\left.\mathrm{CO}_{2}\right)$ are the vital factors for embryonic mortality of duck eggs. Difference in hatchability on fertile eggs was insignificant $(p>0.05)$ between BLRI-1 and BLRI-2 duck. Khatun and Islam (2010) reported higher hatchability of BLRI-1 and BLRI-2 genotypes of ducks as 81 and $86 \%$ which was higher than those the present findings. These results on hatchability of fertile eggs of ducks may be influenced by season, genotypes of ducks, age of breeding flock of ducks, storage condition etc. 
Table1. Fertility, embryonic mortality and hatchability rate of BLRI-1 and BLRI-2 ducks

\begin{tabular}{|c|c|c|c|}
\hline Parameters & $\begin{array}{l}\text { BLRI-1duck } \\
(\text { Mean } \pm \text { SD })\end{array}$ & $\frac{\text { BLRI-2 duck }}{\text { (Mean } \pm \text { SD) }}$ & $\begin{array}{l}\text { Least significant } \\
\text { difference (LSD) }\end{array}$ \\
\hline Fertility (\%) & $65.98 \pm 10.36$ & $59.59 \pm 5.89$ & $* *$ \\
\hline Embryonic mortality (\%) & $24.94 \pm 4.15$ & $35.81 \pm 18.65$ & $* *$ \\
\hline $\begin{array}{l}\text { Hatchability (\%) on fertile } \\
\text { eggs }\end{array}$ & $72.62 \pm 16.95$ & $77.86 \pm 21.55$ & $*$ \\
\hline
\end{tabular}

** Significant at $1 \%$ level $(p<0.01), *$ Significant at $5 \%$ level $(p<0.05) \mathrm{SD}=$ Standard deviation

Table 2. Least squares means with standard deviation for egg weight, duckling weight and their ratio at hatch out day of BLRI-1 and BLRI-2 ducks

\begin{tabular}{|c|c|c|c|}
\hline \multirow{2}{*}{ Parameters } & BLRI-1 duck & BLRI-2 duck & \multirow{2}{*}{$\begin{array}{l}\text { Least significant } \\
\text { difference (LSD) }\end{array}$} \\
\hline & $($ Mean \pm SD) & $($ Mean \pm SD) & \\
\hline Egg weight (g) & $68.56 \pm 6.54$ & $63.04 \pm 5.38$ & $*$ \\
\hline Duckling weight $(\mathrm{g})$ & $40.10 \pm 4.35$ & $36.24 \pm 2.90$ & $*$ \\
\hline Duckling: egg ratio (\%) & $58.44 \pm 0.82$ & $57.49 \pm 0.71$ & NS \\
\hline
\end{tabular}

* Significant at $5 \%$ level $(p<0.05), \mathrm{NS}=$ Non-significant, $\mathrm{SD}=$ Standard deviation

Table 3. Mean and standard error of body weight of BLRI-1 and BLRI-2 ducks at different ages

\begin{tabular}{|c|c|c|c|}
\hline \multirow{2}{*}{ Parameters } & BLRI-1 duck & BLRI-2 duck & \multirow{2}{*}{$\begin{array}{l}\text { Least significan } \\
\text { difference (LSD) }\end{array}$} \\
\hline & $($ Mean \pm SD $)$ & $($ Mean \pm SD $)$ & \\
\hline Day old weight (g/duckling) & $40.10 \pm 4.35$ & $36.24 \pm 2.90$ & $*$ \\
\hline $4^{\text {th }}$ week body weight ( $\mathrm{g} /$ duck $)$ & $378.95 \pm 84.43$ & $359.22 \pm 103.24$ & $*$ \\
\hline $8^{\text {th }}$ week body weight ( $\left.\mathrm{g} / \mathrm{duck}\right)$ & $846.71 \pm 148.06$ & $844.43 \pm 165.82$ & NS \\
\hline $12^{\text {th }}$ week body weight ( $\mathrm{g} / \mathrm{duck}$ ) & $1399.91 \pm 20.20$ & $1313.05 \pm 22.90$ & $*$ \\
\hline
\end{tabular}

* Significant at $5 \%$ level $(p<0.05)$, NS = Non-significant, SD = Standard deviation

Table 4. Productive and reproductive performances of BLRI-1 and BLRI-2 ducks

\begin{tabular}{|c|c|c|c|}
\hline \multirow{2}{*}{ Parameters } & BLRI-1 duck & BLRI- & \multirow{2}{*}{$\begin{array}{l}\text { Least significant } \\
\text { difference (LSD) }\end{array}$} \\
\hline & $($ Mean \pm SD $)$ & $($ Mean \pm SD $)$ & \\
\hline Age at sexual maturity (day) & $158 \pm 0.95$ & $151.75 \pm 1.15$ & $*$ \\
\hline Female weight at first lay (g) & $1444.29 \pm 20.56$ & $1456.22 \pm 24.94$ & NS \\
\hline Egg weight at first lay (g) & $48.87 \pm 0.40$ & $49.50 \pm 0.50$ & NS \\
\hline Egg production $(\%)$ at 40 wks of age & $55.17 \pm 1.04$ & $53.85 \pm 2.03$ & NS \\
\hline
\end{tabular}

* Significant at $5 \%$ level $(p<0.05), \mathrm{NS}=$ Non-significant, $\mathrm{SD}=$ Standard deviation

Egg weight, ducklings weight and ducklings and egg ratio of BLRI-1 and BLRI-2 are shown in Table 2. Egg weight before setting and subsequent duckling weight were determined for BLRI-1 and BLRI-2 ducks. Egg weight averaged to 68.56 and $63.04 \mathrm{~g}$ for BLRI-1 and BLRI-2 ducks, respectively which differed significantly $(p<0.05)$. This result conformed to the findings of Khatun et al. (2007) and Arafa et al. (1982) who reported that egg weight of ducks varied between strains. The duckling weight at hatch of BLRI-1 and BLRI-2 were 40.10 and $36.24 \mathrm{~g}$, 
respectively and the difference was significantly ( $p<0.05)$ influenced by the egg weight. The duckling: egg ratio data showed that there was no significant difference between the ratio of BLRI-1 and BLRI-2 ducks. Mean body weights of BLRI-1 and BLRI-2 ducks at day old, $4^{\text {th }}$ week, $8^{\text {th }}$ week and $12^{\text {th }}$ week of age are shown in Table 3.

Khatun and Islam (2010) reported that mean day old body weight of BLRI-1 and BLRI-2 ducks were 34.69 and $34.54 \mathrm{~g}$, respectively which were lower than those in the present experiment. Difference in body weight at $4^{\text {th }}$ week and $12^{\text {th }}$ week of age were significant $(p<0.05)$ while the body weight of ducks at $8^{\text {th }}$ week did not differ significantly $(p>0.05)$ between BLRI-1 and BLRI-2 ducks.

Productive and reproductive performances of BLRI-1 and BLRI-2 ducks under intensive management system are presented in Table 4. The least squared mean of age at sexual maturity were 158 days and 151.75 days, respectively for BLRI-1 and BLRI-2 ducks and the difference was significant $(p<0.05)$. BLRI-1 duck started to lay eggs almost one week later compared to BLRI-2 duck. The findings of the present study were better compared to the observation of Khatun et al. (2010) who reported that base stock of Rupali and Nageswari duck came to sexual maturity at 166 and 164 days, respectively. The present findings agreed with the results of Huque and Haque (1991) who reported early sexual maturity attributed to the inherent potentialities of improved native breed. Female weights at first lay were 1444.29 and $1456.22 \mathrm{~g}$, respectively for BLRI-1 and BLRI-2 duck, which were not influenced by genotype. Egg weight at first lay was 48.87 and $49.50 \mathrm{~g}$, respectively for BLRI-1 and BLRI-2 ducks but did not significantly differed $(p<0.05)$ by genotype. Khatun et al., (2010) found higher egg weight at first lay of Rupali (43 g) and Nageswari (45 g) duck. Insignificantly ( $p>0.05)$ higher egg production was found in BLRI-1 duck $(55.17 \%)$ than in BLRI-2 duck (53.85\%).

\section{Conclusions}

The findings of the study suggested that the hatchability of BLRI-2 duck was higher than that of BLRI-1 duck although higher embryonic mortality was observed in BLRI-2 duck. The duckling weight at hatch of BLRI-1 and BLRI-2 were 40.10 and $36.24 \mathrm{~g}$, respectively which was significantly higher in BLRI-1 duck genotype. BLRI-1 duck started to lay eggs almost one week later compared to BLRI-2 duck. Further study should be continued for the conservation and improvement of native duck germplasm which will be helpful to maintain the pedigree selection and breeding programs in native duck genotypes.

\section{References}

Arafa, A. S., Harms, R. H., Miles, R. D., Chrismas, R. D. and Choi, J. H. 1982. Quality characteristics of eggs from different strains of hens as related to time of oviposition. Poultry Science, 61: 842847.

Adzitey, F. 2012. Production potentials and the physiochemical composition of selected duck strains-a mini review. On line Journal of Animal and Feed Research, 2: 89-94.

Hamid, M. A., Chowdhury, S. M. K. and Chudhury, S. D. 1988. A comparative study on the performances of growing ducklings of khaki Cambell, Indian Runner and Indigenous ducks under farmer conditions. Indian Journal of Poultry Science, 23(2): 118-121.

Khatun, R., Sarker, M. S.K., Alam, J. and Khatun, H. 2007. Egg quality of different types of native duck germplasm in different age. Bangladesh Journal of Livestock Research, 14(1\&2): 175-183.

Khatun, H. and Islam, M. N. 2010. Multiplication and conservation of foundation flock of Rupali (BLRI-1) and Nageswari (BLRI-2) ducks. Proceedings 
of the annual research review workshop 2010, BLRI, Savar, Dhaka-1341, Bangladesh, 43-46 pp.

Khatun, H., Islam, M. N. and Bhuiyan, A. A. 2011. Performance study of Rupali and Nageswari duck under farmers' condition. Proceedings of the annual research review workshop -2011, BLRI, Savar, Dhaka1341, Bangladesh, 92-95 pp.

Huque, Q. M. E. and Haque, M. E. 1991. A study on the efficiency of desi (local), Khaki Cambell and Jinding duck in an integrated duck-cum-fish farming. Progress report. PPRD, BLRI, Savar, Dhaka, Bangladesh.

Hossain, M. M. 1989. A comparative study on the performance of pure and crossbred ducklings under local conditions. MS thesis. Dept. of Poultry science. BAU, Mymensingh

Huque Q. M. E. and Hossain, M. J. 1991. Production Potentiality of ducks under scavenging condition. Bangladesh Journal of Animal Science. 20(1\&2): 119122.

Hocking, P. M. 2009. Biology of Breeding Poultry, Poultry Science Symposium Series, Volum-29, University of Edinburgh, UK, 224-240 pp.

Islam, M. N., Q. M. E. Huque, Q. M. E., Salahuddin, M. and Sarker, M. S. K. 2003. Potentiality of native genotypes of ducks. Proceedings of the 3rd
International Poultry Show and Seminar, WPSA-BB, 28 February-02 March 2003, Dhaka, Bangladesh, 3: 25-29.

Magor, N. P. 1986. Livestock and poultry component in small farmer development in Bangladesh- a case study. Presented at the Crop-Livestock workshop at Khon Kaen., Thailand.

Olsen, M. W. and Hyne, S. K. 1984. The effect of different holding temperatures on the hatchability of hen eggs. Poultry Science, 27: 420-426.

Pervin, W., Chowdhury, S. D., Ali, M. A., Khan, J. U. and Raha, S. K. 2013 Growth performance of indigenous (desi) ducklings receiving diets of varying nutrient concentrations. Proceedings of the $8^{\text {th }}$ International Poultry Show and Seminar, WPSA-BB, 28 February-02 March 2013, Dhaka, Bangladesh, 45-50 pp.

Singh, H. and Moore, E. N. 1978. Livestock and Poultry Production. Second edition, $355 \mathrm{p}$.

Salam, M. A. and Uddin, M. A. 1987. Bangladesh Hansher chash. Directorate of Livestock Services. Government of the People's Republic of Bangladesh.

SPSS. 1998. SPSS base 15.0 application guide, SPSS Inc., USA

Ukil, M. A. and Islam, M. R. 1991. Rearing and management of poultry in rural Bangladesh. Asian Livestock. XV (9): 135-141. 